\title{
ANALISA KONDENSOR MESIN PENDINGIN ADSORPSI TENAGA SURYA DENGAN MENGGUNAKAN SIMULASI 3D
}

\author{
Dimas B. N. Sitorus ${ }^{1 *}$, Tulus B. Sitorus ${ }^{2}$, Terang $\mathrm{UHSG}^{3}$, Andianto Pintoro ${ }^{4}$ \\ 1,2,3,4 Departemen Teknik Mesin, Fakultas Teknik, Universitas Sumatera Utara \\ Email: sitorus.dimas@gmail.com
}

\begin{abstract}
Energy consumption that is very widely used by humans at this time results in an energy crisis, one of the causes of this event is human dependence on energy derived from fossils where this energy cannot be renewed and will eventually run out. One of the most widely used energy today is in the field of cooling. Making an innovation that allows reduced energy use by obtaining equal results is very necessary. However, making such innovations cannot be made with just one experiment until the innovation can be disseminated. The most efficient way is to use CFD applications. This study aims to determine the fluid phenomena that occur in the condenser system on adsorption refrigeration devices using CFD applications. Simulations were carried out from 12:30 WIB at desorption for 30 minutes and carried out in transient conditions. The results of the simulation are displayed in the form of color contours. The amount of convection heat transfer rate that occurs in the condenser is 1.25 Watts.
\end{abstract}

Keywords: CFD, Evaporataion-Condensation, Condenser, Adsorption, Desorption

\section{Abstrak}

Konsumsi energi yang sangat banyak digunakan oleh manusia pada saat ini mengakibatkan terjadinya krisis energi, salah satu penyebab kejadian ini adalah ketergantungan manusia terhadap energi yang berasal dari fosil yang dimana energi ini tidak dapat diperbaharui dan suatu saat akan habis. Salah satu energi yang paling banyak digunakan saat ini adalah dibidang pendinginan. Pembuatan suatu inovasi yang memungkinkan berkurangnya penggunaan energi dengan mendapatkan hasilnya setara sangatlah diperlukan. Namun, pembuatan inovasi tersebut tidak dapat dibuat hanya dengan sekali percobaan hingga inovasi tersebut dapat disebarluaskan. Cara yang paling efisien ialah dengan menggunakan aplikasi CFD. Penelitian ini bertujuan untuk mengetahui fenomena fluida yang terjadi didalam sistem kondensor pada alat pendingin adsorpsi dengan menggunakan apliaksi CFD. Simulasi dilakukan dari jam 12.30 WIB pada saat desorpsi selama 30 menit dan dilakukan pada kondisi transient. Hasil dari simulasi di tampilkan dalam bentuk kontur warna. Besar laju perpindahan panas konveksi yang terjadi pada kondensor sebesar 1,25 Watt.

Kata kunci: CFD, Evaporasi-Kondensasi, Kondensor, Adsorpsi, Desorpsi 


\section{Pendahuluan}

Konsumsi energi yang sangat banyak digunakan oleh manusia pada saat ini mengakibatkan terjadinya krisis energi, salah satu penyebab kejadian ini adalah ketergantungan manusia terhadap energi yang berasal dari fosil yang dimana energi ini tidak dapat diperbaharui dan suatu saat akan habis [1, 2]. Salah satu energi yang paling banyak digunakan saat ini adalah dibidang pendinginan. Penggunaan energi dibidang pendinginan ini banyak kita jumpai di setiap lantai gedung-gedung besar seperti mall ataupun perkantoran, dan juga banyak di gunakan rumah-rumah penduduk.

Semakin meningkatnya penggunaan energi semakin membuat terjadinya energi krisis, dengan kata lain manusia membutuhkan suatu energi yang ramah lingkungan bagi bumi dan juga energi yang dapat di perbaharui. Salah satu energi itu ialah energi surya atau yang biasa di sebut dengan energi panas matahari.

Penggunaan energi surya dapat diaplikasikan untuk beberapa hal seperti pembangkit lisrik, pengeringan, dan juga salah satunya adalah sebagai pendingin (solar cooling) [3, 4]. Dari beberapa kejadian tersebut membuktikan tingginya kebutuhan terhadap pendingan yang besar dan juga memanfaatkan energi surya yang dapat diperbaharui dengan cukup besar, yang dimana penelitian ini didasari oleh masalah yang sedang dihadapi saat ini.

Metode yang digunakan pada penelitian ini adalah membuat alat pendingin adsorbsi dimana alat ini hanya menggunakan tenaga matahari sebagai penggeraknya dan tidak digunakan energi mekanik.

Penelitian yang sekaligus perkembangan dari alat pendingan adsorbsi ini membutuhkan waktu dan biaya yang banyak. Oleh sebab itu, untuk mengurangi hal tersebut digunakanlah teknologi simulasi. Karena melibatkan aliran fluida, bidang CFD (Computational Fluid Dynamics) dapat digunakan untuk membantu pemodelan proses adsorbsi. Teknologi CFD sekarang ini banyak di gunakan untuk membantu para perancang alat untuk membuat sesuatu hal dengan dengan lebih efisien dan juga dapat lebih cepat mengetahui permasalahan yang terjadi pada alat tersebut.

\section{Metode}

Penelitian ini menggunakan kondensor pada alat pendingin adsorpsi tenaga surya seperti pada gambar di bawah ini.
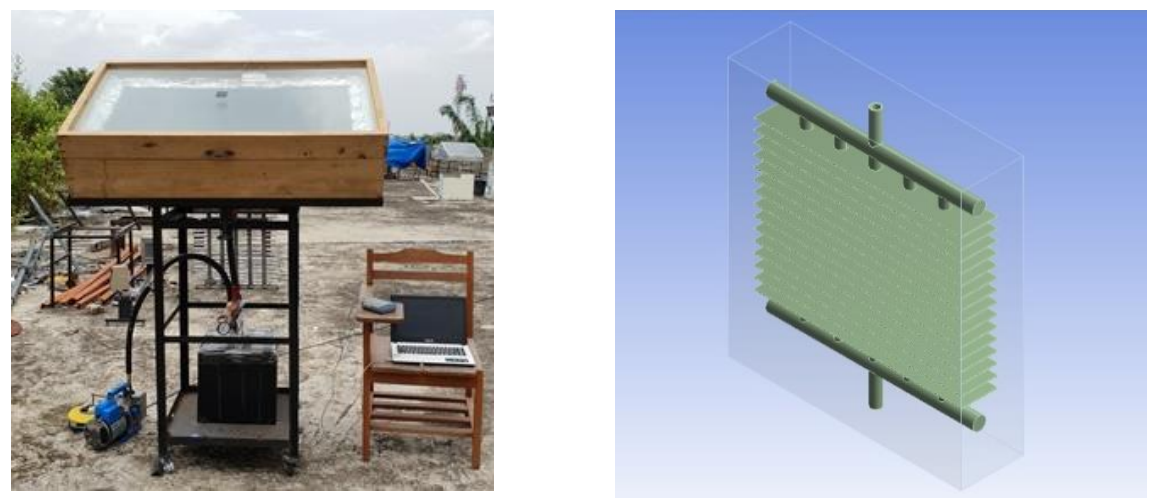

Gambar 2.1 Komponen Kondensor pada Sistem Pendingin Adsorpsi 
Pemodelan dengan metode komputasi pada dasarnya menggunakan persamaan dasar dinamika fluida, dan momentum,. Persamaan-persamaan ini merupakan pernyataan matematis untuk dua prinsip dasar fisika $[5,6]$ :

1. Hukum Kekekalan Massa (The Conservation of Mass)

2. Hukum Kekekalan Momentum (The Conservation of Momentum) sebagai interpretasi dari hukum kedua Newton (Newton Second's Law of Motion)

1. Hukum Kekekalan Massa (The Conservation of Mass) [1]

Konsep utama dari hukum ini adalah laju kenaikan massa dalam volume control adalah sama dengan laju net aliran fluida ke dalam elemen batas. Secara sederhana dapat ditulis:

$$
\frac{\partial M}{\partial t}=\Sigma \dot{\mathrm{m}}_{\text {in }}-\Sigma \dot{\mathrm{m}}_{\text {out }}
$$

Hukum kekekalan massa 3 dimensi secara umum dapat ditulis dengan persamaan berikut:

$$
\frac{\partial \rho}{\partial t}+u \frac{\partial \rho}{\partial x}+v \frac{\partial \rho}{\partial y}+w \frac{\partial \rho}{\partial z}+\rho\left(\frac{\partial u}{\partial x}+\frac{\partial v}{\partial y}+\frac{\partial w}{\partial z}\right)=0
$$

\section{Hukum Kekekalan Massa (The Conservation of Mass)}

Hukum kekekalan momentum ini merupakan interpretasi dari hukum ke-2 Newton (arah sumbux) yaitu :

$$
\sum F_{x}=m a_{x}
$$

Hukum kekekalan masa arah sumbu-x 3 dimensi secara umum dapat ditulis dengan persamaan sebagai berikut:

$$
\rho \frac{D u}{D t}=-\frac{\partial p}{\partial x}+\frac{\partial \sigma_{x}}{\partial x}+\frac{\partial \tau_{y x}}{\partial y}+\rho f_{x}
$$

Dengan cara dan bentuk yang sama persamaan kekekalan momentum 3 dimensi arah sumbu-y dan arah sumbu-z dapat ditulis dengan persamaan sebagai berikut:

$$
\rho \frac{D v}{D t}=-\frac{\partial p}{\partial y}+\frac{\partial \tau_{x y}}{\partial x}+\frac{\partial \sigma_{y y}}{\partial y}+\frac{\partial \tau_{z y}}{\partial z}+\rho f_{y}
$$




$$
\rho \frac{D w}{D t}=-\frac{\partial p}{\partial y}+\frac{\partial \tau_{x z}}{\partial x}+\frac{\partial \tau_{y z}}{\partial y}+\frac{\partial \sigma_{z z}}{\partial z}+\rho f_{z}
$$

(6)

\section{Analisi dan Pembahasan}

\subsection{Kondisi Batas}

Kondisi batas pada penelitian ini ialah simulai dimulai pada pukul 12.30 WIB pada proses desorpsi selama 30 menit. Bahan kondensor adalah alumunium dan fluida yang digunakan ialah uap metanol. Suhu inlet metanol sebesar $35^{\circ} \mathrm{C}$, tekanan sebesar -38663.49 Pa, dan suhu lingkungan sebesar $33.28^{\circ} \mathrm{C}$ dan gravitasi sebesar $9.81 \mathrm{~m} / \mathrm{s}^{2}$.

\subsection{Hasil Simulasi}

Simulasi ini menggunakan Software Ansys 19 dengan pembuatan geometri menggunakan Software Autocad 2016. Gambar-gambar dibawah ini menunjukkan fenomena yang terjadi pada kondensor selama percobaan 30 menit seperti kontur distribusi suhu, kontur tekanan, liquid volume fraction dan besar laju perpindahan panas.

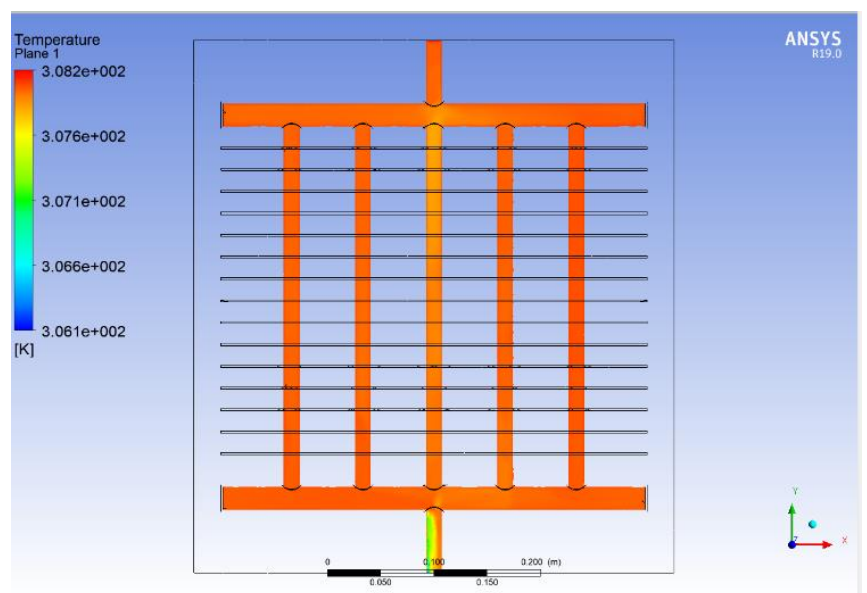

Gambar 3.1 Kontur Temperatur Setelah 30 Menit 


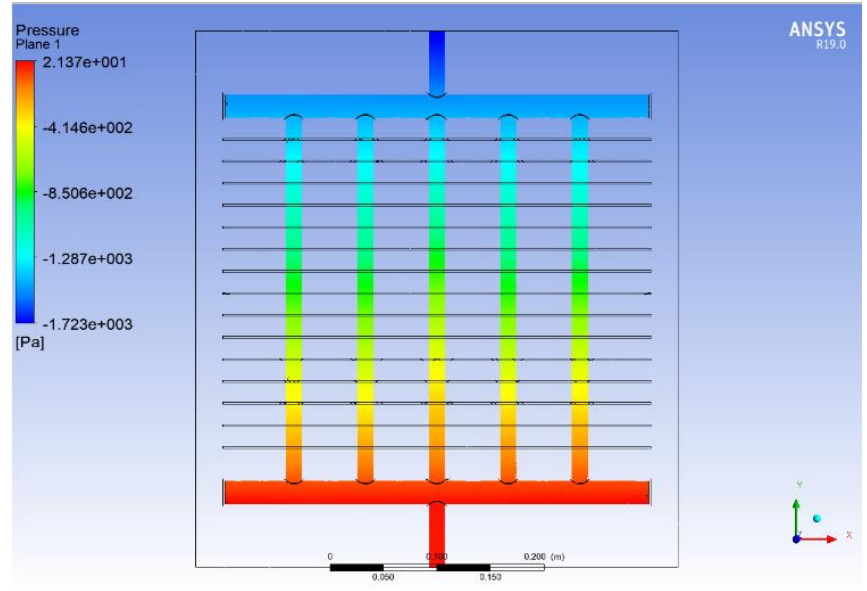

Gambar 3.2 Kontur Tekanan Setelah 30 Menit

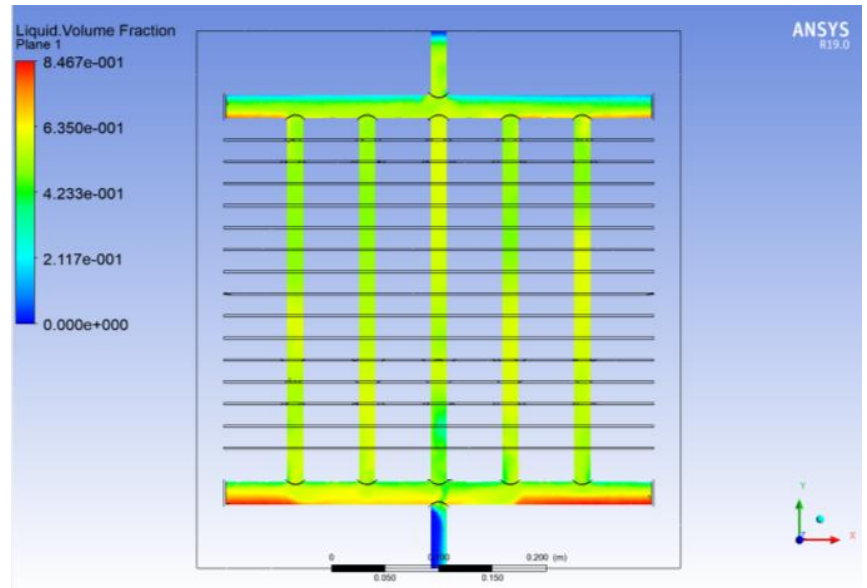

Gambar 3.3 Kontur Liquid Volume Fraction Setelah 30 Menit

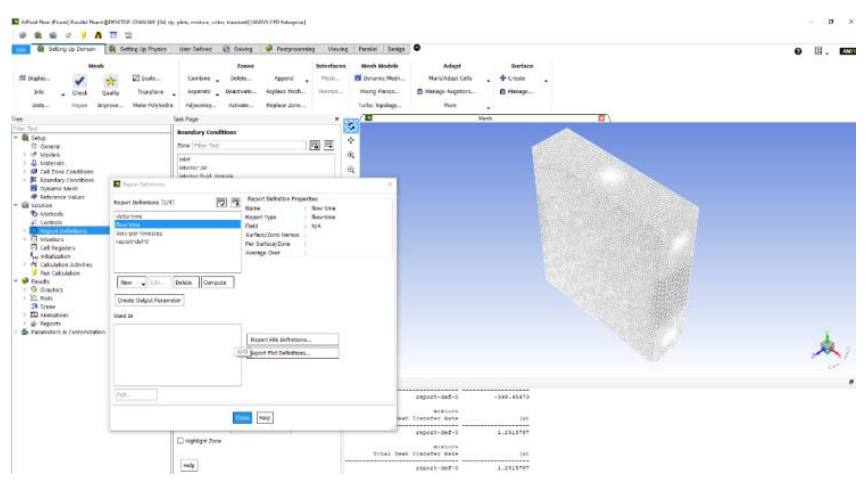

Gambar 3.4 Perpindahan Panas pada Kondensor Setelah 30 Menit 


\section{Kesimpulan}

Dari hasil simulasi 3D mengunakan software ansys 19.0 selama 30 menit diperoleh volume metanol pada fase vapor sebesar $0,0002826 \mathrm{~m}^{3}$ dan volume metanol pada fase liquid sebesar 0,0003146 $\mathrm{m}^{3}$. Berdasarkan data dari simulasi menggunakan Software Ansys 19.0, bahwa distribusi temperatur pada kondensor pada menit awal sebesar 308,15 K, selanjutnya pada menit ke-10 sebesar 307,85 K, dan pada menit ke-20 sebesar 308,06 K, dan pada menit terakhir simulasi yaitu menit ke-30 temperatur pada kondensor didominasi pada temperatur $307.61 \mathrm{~K}$. Dan, besar laju perpindahan panas konveksi yang terjadi pada kondensor adalah sebesar 1,25 Watt. Nilai ini merupakan pada proses selama 30 menit. Dan memiliki efisiensi sebesar 49,19\%.

\section{Referensi}

[1] Watheq Khalil Said Hussein, Solar Energy Refrigeration by Liquid-Solid Adsorption Technique, Egypt, (Thesis 2008)

[2] Zhang X.J., R.Z. Wang, Design and performance simulation of a new solar continuous solid adsorption refrigeration and heating hybrid system, Renewable Energy 27, pp.401-415, Elsevier, 2002.

[3] Wang L.W., R.Z. Wang, Z.S. Lu, C.J. Chen, J.Y. Wu, Comparison of The Adsorption Performance of compound Adsorbent in a Refrigeration Cycle with and without Mass Recovery, Elsevier Journal, 2006.

[4] Wang L.W., R.Z. Wang, R.G. Oliveira, A review on adsorption working pairs for refrigeration, Renewable ans Sustainable Energy Reviews 13 pp.518-534, 2009.

[5] Qu T.F., R.Z. Wang, W. Wang. Study on heat and mass recovery in adsorption refrigeration cycles. Applied Thermal Engineering 21 (2001) pp.439 - 454

[6] Critoph E.R., S.J. Metcalf. Specific cooling power intensification limits in ammonia-carbon adsorption refrigeration systems. Applied Thermal Engineering 24 (2004) pp. 661-678. 